\title{
MIR133A2 Pre-miRNA
}

National Cancer Institute

\section{Source}

National Cancer Institute. MIR133A2 Pre-miRNA. NCI Thesaurus. Code C82767.

MIR133A2 is an oligoribonucleotide that is encoded by the human MIR133A2 gene and has a role in the regulation of gene expression. 